RAINBOW Vol. 9(2) 2020
UNournal of Literature, Linguistics and
Cultural Studies
https://journal.unnes.ac.id/sju/index.php/rainbow

\title{
Function of The Language Style Used in Women Commercial Product Advertisements: A Stylistic Analysis of Language
}

\author{
Sinta Putri Amelia Ginting* ${ }^{\star 凶}$, Rahmadsyah Rangkuti**, Muhammad Yusuf*** \\ $*, * *, * * *$ Department of English, Faculty of Cultural Studies, University of Sumatera Utara, Indonesia
}

\begin{tabular}{|c|c|}
\hline Article Info & Abstract \\
\hline $\begin{array}{l}\text { Article History: } \\
\text { Received } \\
4 \text { August } 2020 \\
\text { Approved } \\
29 \text { October } 2020 \\
\text { Published } \\
30 \text { October } 2020\end{array}$ & $\begin{array}{l}\text { The objectives of this research are to find out the types of the language style used in } \\
\text { selected Woman Commercial Product Advertisement and to explain the function of } \\
\text { language style in selected Woman Commercial Product Advertisement. The concept of } \\
\text { stylistic is analyzed by using William Wells's theory which discussed about language } \\
\text { style. A qualitative research method is used in analyzing this research. The result of this } \\
\text { research shows that some types of language style are found in the data. From } 10 \\
\text { advertisements analyzed, the researcher found } 4 \text { hard cell styles, } 3 \text { soft cell styles, } 2 \text { slice } \\
\text { of life styles, and } 1 \text { demonstration style. Hard cell style mostly appears in women } \\
\text { product's advertisements because the advertiser mostly used a rational informational } \\
\text { message that is designed to touch the mind and to create a response based on logic. }\end{array}$ \\
\hline & a \\
\hline
\end{tabular}

\section{INTRODUCTION}

According to Sapir (2020) language is a purely human and non instinctive method of communicating ideas, emotions, and desires by means of a system of voluntarily produced symbol. It means that language plays a crucial role and a vital role in human life and also has many advantages of many various aspects of human life. To communicate and establish relationship with other, people use language as tool of their communication (Wardhaugh, 2009).

In human communication, there are two kinds of language, spoken language and written language. Spoken language is an utterance which is formed from sound, such as conversation, speech, storytelling, discussion, radio, television broadcast, and etc. While, written language is an utterance which is formed in the written form, such as novels, comics, newspapers, magazines, letters, books, journals, articles, and etc. In expressing or delivering ideas in both forms, spoken and written language, people have and use their own style because it is related to the social aspect. According to Eckert (2002) language style is pivotal construct in the study of sociolinguistics variation. Variation or diversity of languages is the main subject of discussion in sociolinguistics, so Kridalaksana (Chaer and Agustina, 1995) defines sociolinguistics as a branch of linguistics that is trying to explain the characteristics of language variation and the correlation variation in the language of the social characteristic.

According to Chaika (1982) style refers to the selection of the linguistic forms to convey social artistic effects. Style also acts as a set of 
instructions. Other opinions come from Keraf (2002) states that style is the ability and the competence to make a sentence in a good way. This statement clarifies that the style used will influence the meaning and it is used for certain reason due to the situation. The researcher enthusiastically will focus the study on the language style because style forms communication in the right way and determines how a social interaction will proceed. In this case, style determines how a speaker speaks and how the listener takes the meaning of the communication in the right way; whether it is serious, humorous, dubious, or any other possible senses.

According to Wells (1995) there are several styles of advertisement formulas the message. These include hard sell, soft sell, lecture and drama, straight forward, demonstrations, comparison, problem solution, slice of life, and spokesperson.

Advertisement is selected as a data of this research for several reasons. Advertisement is is a marketing communication that employs an openly sponsored, non-personal message to promote or sell a product, service or idea (Stanton 1984) and according to Lapsanska (2006) advertisement is one of human life activities that can be found in radio, television, magazine, newspaper, and other source.

This research discussed about the language style used in commercial advertisement on television which focused on the kinds of language style and also investigate how the language style are used in women commercial product.

Language is a purely human and non instinctive method of communicating ideas, emotions, and desires by means of a system of voluntarily produced symbol (Sapir, 2020). It means that language plays a crucial role and a vital role in human life and also has many advantages of many various aspects of human life. To communicate and establish relationship with other, people use language as tool of their communication (Wardhaugh, 2009).

\section{METHODS}

In the analysis of stylistic on woman commercial products advertisements, an arrangement of research designs is needed to support the statements that have been written in this thesis.

Therefore, simplification of methods is needed. The method used coherently in analyzing certain data from advertisements to support this analysis is a descriptive qualitative method. According to Nazir (2005) descriptive method is a method of research that makes the description of the situation or event or occurrence. It will be used in analyzing the data by giving a description about five language styles. Even the writer uses the percentage too, but at the conclusion it will give an explanation. According to Sukmadinata (2006) qualitative research is one of the research procedures which produce descriptive data in form of speech or writing, and the behavior of those observed. A qualitative approach is expected to produce in-depth description of the speech, writing, and or observable behavior of an individual, group, community, or organization and within a particular context setting is examined from the viewpoint of complete, comprehensive, and holistic. Using this method, researchers describe and analyze certain data and provide interpretations about it based on related books regarding subject matter. Data come from all texts those transcripts from the advertisements video on YouTube.

The researcher chose 10 women commercial advertisements to be analyzed and those are SKII, Lancome Paris, Make Up Forever, Sephora, Maybelline, L'oreal, Lamer, Clinique FT, Avon, and Clarins. The ten brands are very influential and famous because each company get millions of followers from around the world. Data come from all texts those transcripts from the advertisements video on YouTube and the The researcher analyze those transcript from their advertisement by using a theory of William Wells that classified style of language into 9 styles. They are hard sell, soft sell, 
lecture and drama style, straight forward style, demonstration style, comparison style, problem of solution style, slice of lifestyle, and spokesperson style.

Interpretations based on qualitative descriptive methods of transcription text from the YouTube video must be coherent with the langua style term which is the focus of this thesis and must be able to support the thesis writer in summarizing the conclusions in the last chapter.

\section{RESULTS AND DISCUSSION}

DATA 1

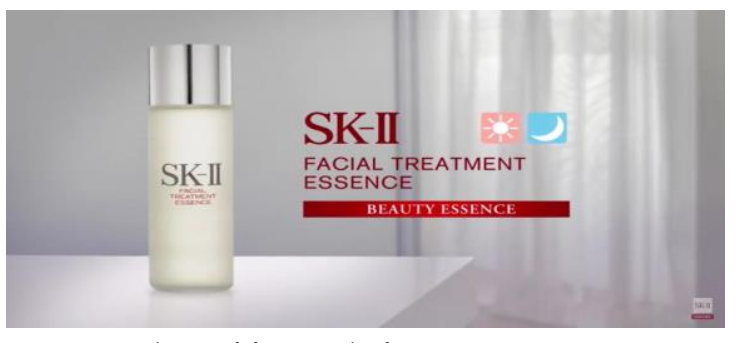

https: //youtu.be/54Im_-IRABo

SK II facial treatment essence

Dispensed approximately $4.5 \mathrm{~cm}$ in diameter onto a cotton pad

Gently pat the entire face from the center of the face outward

Starting with any areas of concern and moving from the cheeks forehead

around the eyes bridge of the nose to the neck area

For approximately 4.5 in diameter onto your cupped palm, rub hands together

And gently pat the entire face working from the center of the face

outward starting with any areas of concern and moving from the cheeks forehead around

the eyes bridge of the nose and wings of the nose to the neck area.

The advertisement above is a skincare product advertisement of SK II. This product works to makes you possible to look up glowing like a crystal and younger. The SK-II Facial Treatment Essence helps to improve the appearance of 5 dimensions of beautiful, crystal clear skin: spots are less visible, appearance of wrinkles is reduced, skin texture is more refined, firmness is improved, and radiance is beautifully elevated.

Language style that used of this advertisement is demonstration. The demonstration style is the way of delivered an ideas or message which is focused on how to use the product of what it can do for you. The product strengths take center stage.

This can be seen in from the commercial video, the advertiser show the customer how to use SK-II facial treatment essence properly so that they can get the best result.

There are some steps to get the crystal clear skin which costumer should do. The advertiser explains it clearly and it can help them. By knowing how to use the product, the costumer will be interest to use the product and hopefully can be success with the crystal clear skin.

\section{DATA 2}

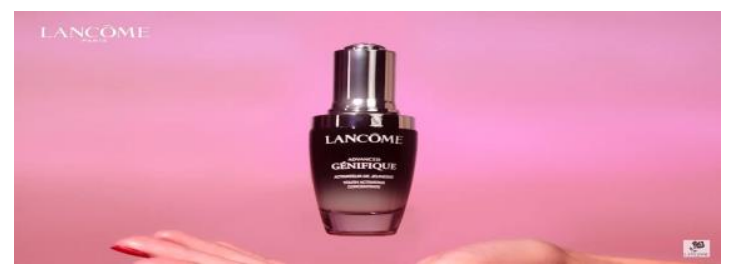

https: / /youtu.be/Z8ewXwUP02w

Happiness is my superpower

Freeze happiness in time

Hypnotize with happiness

Multiply happiness

Turn 'la vie en rose'

Make this happiest Halloween

The advertisement above is a cosmetic product advertisement of Lancôme Paris. This product works to makes you look amazing especially in celebrating Halloween. At Lancôme, their mission is to make the clients look beautiful and leave feeling happier. That's why in the commercial, the advertiser use the word 'happiness' for five times.

Language style that used of this advertisement is soft cell. Soft sell use an emotional message and it is designed around an image intended to touch the heart and to create a response based on feeling and attitude. The message present with subtle, intriguing, and ambiguous illustrates how advertisement sell 
moods and dreams more than product feature. This can be seen in from the commercial video, the advertiser show the customer how to be a beautiful and happiness women by using this product. They persuade the costumer with the slogan "happiness is my superpower". It make the word "happiness" is a key of beauty. Beside that, the advertiser shows that if we use the product, everybody will be hypnotized with our beauty. Moreover it can make the women as a star and amazing so that they all be happy. In other hand the advertiser invite the women to be happy and use the product to be mesmerizing.

DATA 3

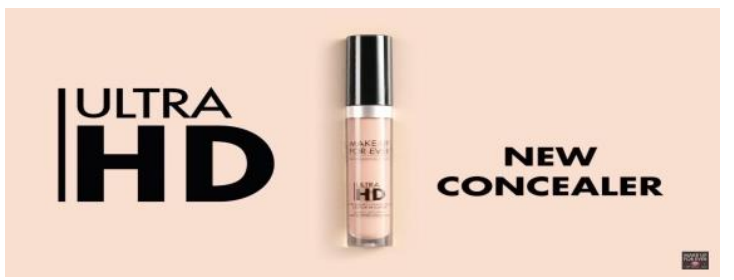

https://youtu.be/Z7Mz1_-AdCE Ultra HD

New Concealer

$12 \mathrm{H}$ self-setting

Light capturing

Get closer

22 shades for all skin tones

Your makeup is invisible.

The advertisement above is a cosmetic product advertisement of Makeup Forever. This product works to makes you look younger and more confident with the wrinkles. This product, concealer covers all, looks natural on skin, and lasts for an incredibly long time. And while it's a bit more of an AP-level makeup product (it's not as simple to slap on as say, a cream concealer in a pot, or a liquid concealer in click-pen form), it's totally worth the learning curve and teensy bit of extra effort. Right out of the tube, the liquid formula - it comes in 14 shades, several of which are color correctors - resembles the runny consistency of foundation, but to the touch it feels denser and creamier. There isn't a zit, dark spot, splotchy patch, or under eye circle this concealer can't cover up, thanks to the structure of the pigments that help to diffuse light, making it an ace at erasing and blurring. The formula is also incredibly pigmented, which is surprising considering how lightweight it is and how seamlessly it blends over your skin.

Language style that used of this advertisement is Hard cell. Hard sell is rational informational message that is designed to touch the mind and to create a response based on logic. The approach of this style is direct and emphasizes tangible product features, facilities and benefits. This can be seen in from the commercial video, the advertiser show the customer how to get closer with anybody in confident. The advertiser show that this product can cover your wrinkles perfectly and you can show up yourself without a worry. This product has a best formula that can make your make up is invisible. With this product, the advertiser persuades the women especially for elderly women to say no to wrinkles in eyes. This product is totally perfect to increase their confident and can make them look younger. Moreover, the costumer will believe that the beauty belong to anybody.

\section{DATA 4}

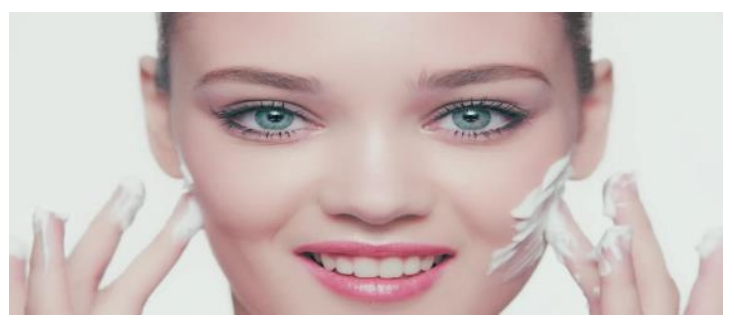

https://youtu.be/meoFW_73wRo

Where beauty beats experiment, explore, desfrute

The advertisement above is a cosmetic product advertisement of Sephora. This product works to makes you look more attractive, amazing and aromatic. Sephora is the woman's No.1 destination for everything beauty. This product provides the costumer to have a best makeup.

Language style that used of this advertisement is soft cell. Soft sell use an emotional message and it is designed around an image intended to touch the heard and to create a response based on feeling and attitude. The message present with subtle, intriguing, and ambiguous illustrates how advertisement sell 
moods and dreams more than product feature. This can be seen in from the commercial video, the advertiser show the customer how to be an attractive and aromatic women by using this product. They persuade the costumer with the slogan "where beauty beats experiment, explore, desfrute". In addition, the advertiser persuades the costumer especially the makeup lover to have the product. When it comes to serving face, this product has got them covered. Whether they have a favorite brand or need help finding the perfect match, Sephora is your No.1 destination for everything beauty. Moreover, this product gives the pressure if you're looking for the best makeup; a good place to start is with their bestsellers. The costumer can read thousands of reviews from fellow makeup-lovers and find top rated products for your beauty routine.

\section{DATA 5}

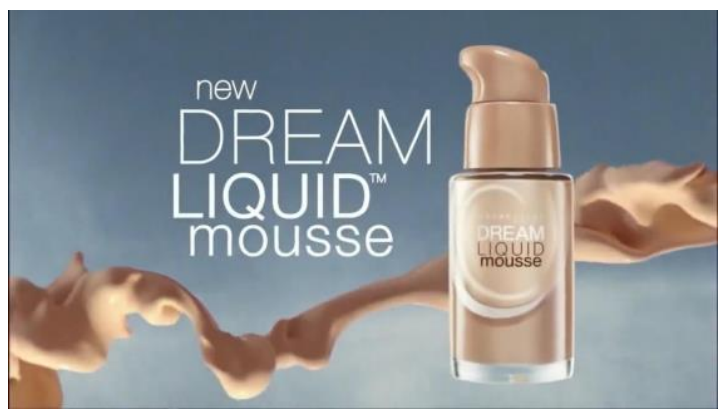

https://youtu.be/MTgeUVOxI8E

Flawless skin?

$100 \%$ pore less perfection has arrived

New dream liquid mousse foundation from Maybelline New York

A new liquid sensation its air whipped for $100 \%$ pore less perfection

Other sink and exaggerated pores are foundation cushions as it blends pores vanish

skin look smoother perfect.

Could beyond flawless to $100 \%$ for less perfection you dream liquid mousse

foundation.

The advertisement above is a cosmetic product advertisement of Maybelline. This product works to makes you have a flawless skin with $100 \%$ pore less perfection. It is a dream Satin Liquid foundation + hydrating serum delivers the looks of completely poreless skin. Achieve the look of completely poreless skin with a smooth airbrushed finish. Lightweight and breathable, this up to 16-hour liquid foundation delivers cakefree, full coverage that moisturizes all day.

Language style that used of this advertisement is Hard cell. Hard sell is rational informational message that is designed to touch the mind and to create a response based on logic. The approach of this style is direct and emphasizes tangible product features, facilities and benefits. This can be seen in from the commercial video, the advertiser shows the customer how to get the flawless skin and look smoother perfect. The advertiser show that this product can delivers the looks of completely poreless skin. This product persuade the costumer with a new dream liquid mousse foundation from Maybelline New York. A new liquid sensation its air whipped for $100 \%$ pore less perfection. Other sink and exaggerated pores are foundation cushions as it blends pores vanish skin look smoother perfect. This product is totally perfect to disguise the pore in face so that every women can get the perfect makeup.

\section{DATA 6}

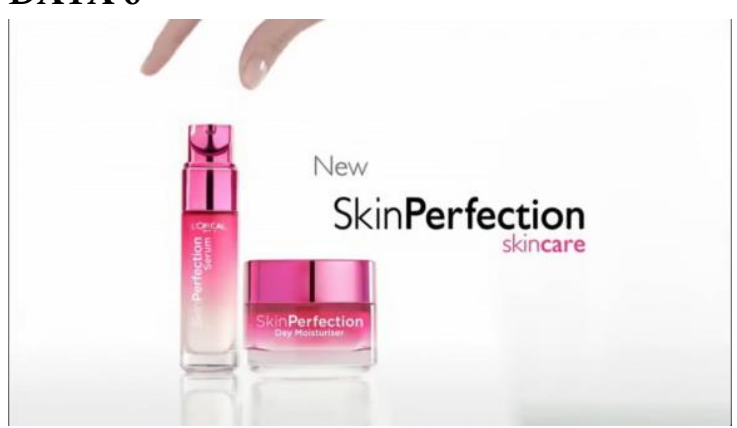

https://youtu.be/JoMM4wyzY-E

What if you could transform your skin to look pixel perfect?

Perhaps take new skin perfection by L'Oreal advanced skincare with powerful

formulas helps transform the appearance of skin quality texture feels silky soft pores

look virtually undetectable tone appears.

More even look fooled already from every angle new skin.

Perfection by L'Oreal Paris pixel perfects your skin where worth it. 
The advertisement above is a cosmetic product advertisement of L'Oreal. This product works to makes you have a new skin perfection. This product is L'Oreal advanced skincare with powerful formulas helps transform the appearance of skin quality texture feels silky soft pores look virtually undetectable tone appears. More even look fooled already from every angle new skin. Language style that used of this advertisement is Hard cell. Hard sell is rational informational message that is designed to touch the mind and to create a response based on logic. The approach of this style is direct and emphasizes tangible product features, facilities and benefits. This can be seen in from the commercial video, the advertiser shows the customer about the product feature and benefits. The advertiser show that this product is harness the power of their circadian rhythm with clinically proven, nutrient rich supplements. The nutrient rich support for optimum health and beauty 24/7. This product persuades the costumer to take new skin perfection by L'Oreal advanced skincare with powerful formulas helps transform the appearance of skin quality texture feels silky soft pores look virtually undetectable tone appears. By seeing this commercial, the women will get perfection by L'Oreal Paris pixel perfects your skin where worth it.

\section{DATA 7}

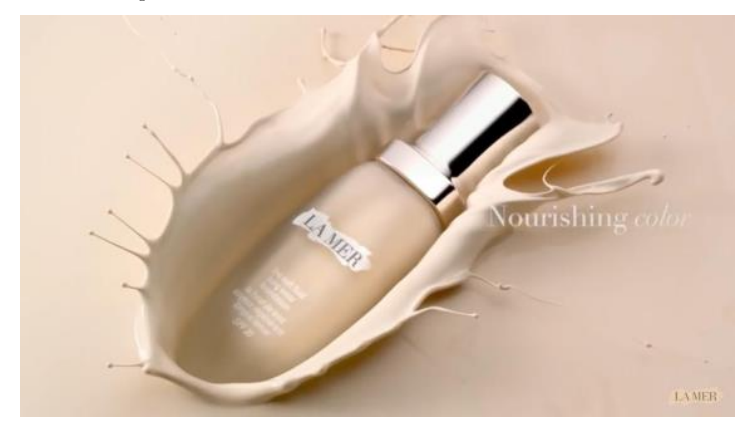

Beauty beyond skincare

The soft fluids long wear foundation SPF 20

Healing energy

Nourishing color

The softest shades

From the sea

Skin color De La Mer
The advertisement above is a cosmetic product advertisement of Lamer. This product works to makes you look beauty and flawless. This product provides a weightless texture meets luxurious, long wear. NEW Soft Fluid Long Wear Foundation SPF 20 seamlessly blends soft color, healing hydration and Miracle Broth. Pores look refined. Imperfections virtually disappear. SPF and antioxidants help protect a newly flawless complexion. New color capsule technology helps color stay true - even in humidity. Language style that used of this advertisement is soft cell. Soft sell use an emotional message and it is designed around an image intended to touch the heard and to create a response based on feeling and attitude. The message present with subtle, intriguing, and ambiguous illustrates how advertisement sell moods and dreams more than product feature. This can be seen in from the commercial video, the advertiser show the customer how to be more beauty with the nourishing color and the softest shades by using this product. They persuade the costumer with the slogan "beauty beyond skincare". In addition, the advertiser persuades the costumer with the formula of the product is the soft fluid long wear foundation SPF 20, healing energy, nourishing color and the softest shades from the sea. With the formula, the advertiser makes the costumer interested and persuaded.

\section{DATA 8}

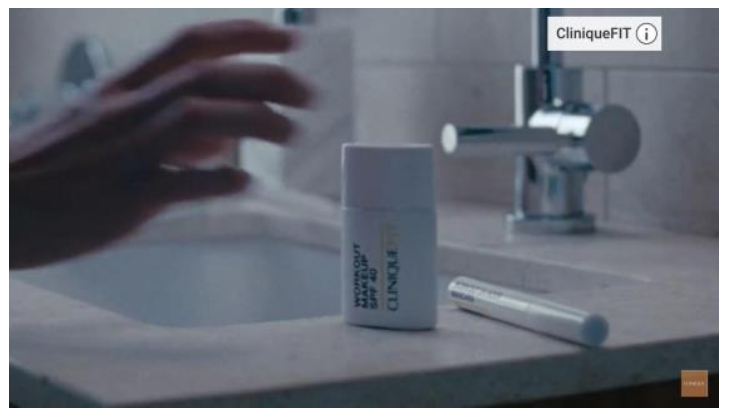

https://youtu.be/EL8F4nMwv_k

Life is a Marathon

Look good running it

Life proof

Endurance tested. 
The advertisement above is a cosmetic product advertisement of Clinique FIT. This product works to makes you look beauty otherwise you are a high performance women. This product provides High-performance fitness makeup and skin care for your active lifestyle. Its lifeproof and sweatproof makeup for everyday. This make up is suitable for working out.

Language style that used of this advertisement is the slice of life. The slice of life is an elaborate version of a problems-solution message presented in the form of a little drama. It uses some commonplace situation with "typical people" talking about the problems. This can be seen in from the commercial video, the advertiser show the life of modern women with high performance.

Usually some makeup creates for low performance activities so that they can keep the makeup softly. In the commercial, the advertiser show the needed of the women in having make up. Most of them need the workout makeup that introduced in this product. The Workout Makeup $(\mathrm{P} 1,850)$ was designed to consider outdoor activities and thus formulated with SPF40 $\mathrm{PA}+++$. Despite the sunscreen feature, the formula is runny, dries fast, and doesn't leave a white cast. The shade I got from the press kit is 63 Deep. It is beige-toned and would probably suit NC20-NC30 skin better, but the coverage is sheer enough that it I'm able to use it for a liquid bronzer/tinted moisturizer effect. Two passes are enough to take care of my skin's usual redness, but blemishes and hyperpigmentation are still visible and require concealer. It can totally persuade the costumer especially the high performance women to have this product.

\section{DATA 9}

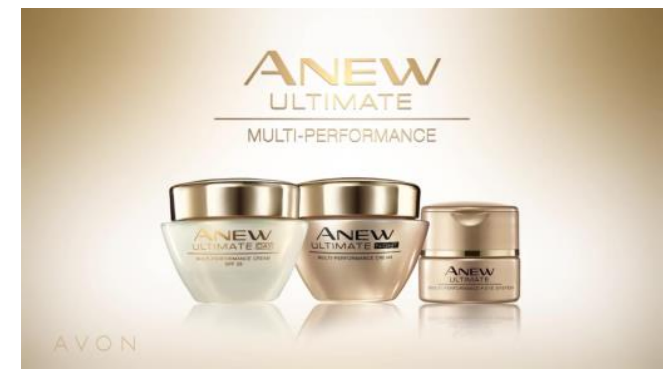

https://youtu.be/Wdp3dGR2UeQ
The wait is over

Beautiful skin you've arrived

From Avon Anew comes

The gold standard of skin care

Ultimate multi performance collection

Three products one beautiful result

Visibly youthful revived skin

A new ultimate addresses the multiple signs of aging

Leaving your skin luxuriously transformed

Ultimate multi performance

Day cream, night cream and eye system help optimize skin cells by clearing away

damage

The formula leaves skin looking its best

Developed by the Avon skin care institute the exclusive sell UV of complex formulated

with legendary Tilliacore an Asian plant known for its healing properties helps skin

cells function at peak youthful levels and skin begins looking younger too.

The ultimate effect is so revolutionary

It triggers a series of benefits to visible improve the look of multiple signs of aging

Smoother texture, improve radiance more even skin tone

Decreased wrinkles and faded discoloration

Now when it comes to beautiful skin, you can have it all

Experience Anew ultimate multi performance collection for yourself

Call your Avon representative or go to avon.com now.

The advertisement above is a cosmetic product advertisement of Avon. This product works to makes you have beautiful skin with the gold standard. Avon revolutionized the world of skincare with the launch Anew. Anew pioneers transformative, anti- aging skincare technology to help women look years younger.

Language style that used of this advertisement is Hard cell. Hard sell is rational informational message that is designed to touch the mind and to create a response based on logic. The approach of this style is direct and emphasizes tangible product features, facilities and benefits. This can be seen in from the commercial video, theadvertiser shows the customer about the product feature and benefits. 
The advertiser shows the formula and benefits of this product. The formula leaves skin looking its best. Developed by the Avon skin care institute the exclusive sell UV of complex formulated with legendary Tilliacore an Asian plant known for its healing properties helps skin cells function at peak youthful levels and skin begins looking younger too. The ultimate effect is so revolutionary. It triggers a series of benefits to visible improve the look of multiple signs of aging; Smoother texture, improve radiance more even skin tone; Decreased wrinkles and faded discoloration. By informing all the strengthens of this product, it can persuade the costumer to have the product.

\section{DATA 10}

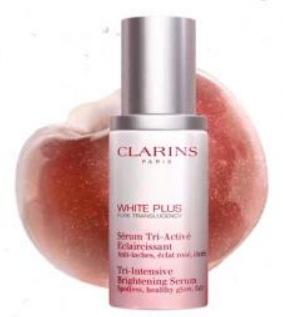

https://youtu.be/IEPhvfehopo

No matter where life takes you

It's all about you taking control of your skins

Translucency Clarins introduces the new white plus pure translucency serum

It visibly prevents and reduces dark spot and skin over pigmentation

Thanks to powerful acerola extract

Say hello to fairer spotless and translucent skin with a healthy glow

New white plus pure translucency serum

Clarins, It's all about you.

The advertisement above is a cosmetic product advertisement of Clarins. This product works to makes you look beauty otherwise you are a work out women. This product provides High-performance serum and makeup for your active lifestyle indoor and outdoor. No matter where life takes you. It's all about you taking control of your skins. It is one of the commercial's slogan.

Language style that used of this advertisement is the slice of life. The slice of life is an elaborate version of a problems-solution message presented in the form of a little drama. It uses some commonplace situation with "typical people" talking about the problems. This can be seen in from the commercial video, the advertiser show the life of modern women with high performance. In the commercial, the advertiser show the needed of the modern women in having make up. Most of them need the workout makeup that introduced in this product. This product also persuades the costumer in giving the solution to keep their skin from sun rises. Translucency Clarins introduces the new white plus pure translucency serum. It visibly prevents and reduces dark spot and skin over pigmentation. Thanks to powerful acerola extract that help this skincare to keep the skin performance. The woman feel more confident to fairer spotless and translucent skin with a healthy glow by using new white plus pure translucency Serum.

From the analysis above, the writer found that hard cell style mostly appears in women product advertisements. This style is in the first rank because it appears four times advertisements. The second rank is soft cell style which appears three times from ten advertisements. The third rank is slice of life style which appears two times from ten advertisements and in the last rank is demonstration style which appears only once from ten advertisements.

\section{CONCLUSION}

The researcher used William wells theory in analyzing the data. The researcher found the types of language style in advertisement. They can be divided into ten types of language style, namely: hard sell, soft sell, lecture and drama, straight forward, demonstrations, comparison, problem solution, slice of life, and spokesperson. Advertisement on internet that using a good style can be easy to convey the main message, so that readers or viewers get the point from advertisement.

To make the viewers interested to see the advertisement there are some strategies to create an advertisement, one of them is making creative 
sentence by finding magic words because words are powerful tool in advertising beside the interested picture or model which the viewer see for the first time. The style in the advertisements can support and create an interesting meaning as long as it can persuade the reader's interest and they are attracted to buy the product.

\section{REFERENCES}

Chaer and Agustina. (1995). Sosiolinguistik: Perkenalan Awal. Jakarta: Penerbit P.T. Rineka Cipta.

Chaika, Elaine. (1982). Language the Social Mirror. Massachusets: Newbury House Publishers,Inc.

Eckert, P. R. J. R. (2020). Style and Sociolinguistic Variation (Paperback) - 2002 Edition. CAMBRIDGE UNIVERSITY PRESS.

Keraf, Gorys. (2002). Diksi dan Gaya Bahaya. Jakarta: Pustaka Utama.

Lapsanska, J. (2006). The Language of Advertising with the Concentration on The Linguistic Means and the Analysis of Advertising Slogans. (Online) (http://diplomovka.sme.sk/zdroj/3091.pdf , retrieved on 02 January 2020.

Nazir. (2005). Metode Penelitian. Bogor: Ghalia Indonesia.

Sapir, E. (2020). Language: An Introduction to the Study of Speech 1921 [Leather Bound]. Generic.

Stanton, William J. (1984). Fundamentals of Marketing. 8th Edition. Mc Graw Hill.

Sukmadinata. (2006). Metode Penelitian Kualitatif. Bandung: Graha Aksara.

Wardhaugh, R. (2009). An Introduction to Sociolinguistics (6th ed.). Wiley-Blackwell.

Wells, William. (1995). Principle and Practice. United State of America: A Dulmen and Schuster Company. 